\title{
EPIDURAL MORPHINE \\ CAUSES DELAYED AND PROLONGED VENTILATORY DEPRESSION
}

\author{
R.L. Knill, J.L. Clement and W.R. Thompson
}

\begin{abstract}
We measured ventilation, $\mathrm{PET}_{\mathrm{CO}_{2}}$ and the ventilatory response to added carbon dioxide before and at intervals up to six hours after epidural morphine $3.5 \mathrm{mg}$ and $7.0 \mathrm{mg}$, and before and after subcutaneous injections of the same dose in volunteers. Subcutaneous morphine increased $\mathrm{PET}_{\mathrm{CO}_{2}}$ slightly, but did not alter the sensitivity of the response to added carbon dioxide. Epidural morphine reduced ventilation and increased $\mathrm{PET}_{\mathrm{CO}_{2}}$ progressively with time and, six hours after injection, reduced the ventilatory response to carbon dioxide considerably. In two subjects tested, these ventilatory effects persisted for twenty-four hours. The added effects of epidural morphine were due primarily to reductions in tidal volume and the tidal volume response to added carbon dioxide. We conclude that epidural morphine causes delayed and very prolonged ventilatory depression, which is of a greater magnitude and a different ventilatory pattern than that which follows the same dose of morphine given subcutaneously. Ventilatory depression after lumbar epidural morphine develops slowly, as the lower limb analgesic effect is waning.
\end{abstract}

Key Words: Epidural Morphine, Ventilation, depression.

THE MOST IMPORTANT FACTOR limiting the safe dose of parenteral narcotic is the risk of excessive ventilatory depression. Intrathecal and epidural narcotic were initially considered to be relatively free of this risk, because of the very small doses of narcotic usually administered. However, there are now several reports of profound ventilatory depression or ventilatory arrest in patients 4-12 hours after intrathecal or epidural morphine in doses of only $1-5 \mathrm{mg} .^{1-4}$

Two previous studies of healthy volunteers suggest that a single small dose of epidural narcotic has no significant effect on the ventilatory response to added carbon dioxide. ${ }^{5,6} \mathrm{How}$ ever, neither group considered carbon dioxide responses beyond three hours after an injection and neither reports values of unstimulated ventilation or $\mathrm{PCO}_{2}$. The purpose of this study was to assess possible ventilatory effects of a single dose of epidural morphine in volunteers in a more complete fashion.

R.L. Knill, M.D., F.R.C.P.(C), Associate Professor J.L. Clement, R.N.; W.R. Thompson, M.B., B.S., F.F.A.R.A.C.S., Fellow (Present address: Sir Charles Gairdner Hospital, The Queen Elizabeth 11 Medical Centre, Nedlands, W. Australia), Department of Anaesthesia, University of Western Ontario, London, Canada.

This study was supported by The Medical Research Council of Canada, Grant MA 6443.

Reprint requests to: Dr. R.L. Knill, Department of Anaesthesia, University Hospital, P.O. Box 5339, Postal Station A, London, Ontario, Canada N6A 5A5

\section{METhoDS}

The study was approved by the University of Western Ontario Committee on Human Research.

The subjects were four healthy male volunteers, who had been informed of the nature and known risks of the study and had given written consent. All were experienced in studies of ventilatory control. Their ages, weights and heights were respectively $33 \pm 2$ years, $70.3 \pm$ $3.7 \mathrm{~kg}$ and $178 \pm 8 \mathrm{~cm}$ (means \pm S.D.).

We planned to measure ventilatory variables before and after epidural morphine 3.5 and $7.0 \mathrm{mg}$, and also before and after the same doses given subculaneously. Each dose-route combination was to be studied in each subject on a separate day. The study was conducted in conjunction with an evaluation of analgesic effects, which are described in an accompanying report. ${ }^{7}$

Subcutaneous morphine was administered into the upper arm and epidural morphine into the lumbar region at the $L_{3}-L_{4}$ interspace. Ventilatory measurements were made within the hour before each morphine administration, and then at $30,90,150,240$ and 360 minutes thereafter. In two subjects after epidural morphine $3.5 \mathrm{mg}$, measurements were repeated at 24 and 48 hours.

Throughout all measurement periods, the subject rested supine on a comfortable stretcher with the room lights dim and quiet music playing on a radio. During the tests he breathed through a mouthpiece with nose-clips firmly in place. After 
the subject had inhaled air from a non-rebreathing system for several minutes. and if the endtidal carbon dioxide concentration was steady, we recorded a one minute period of ventilation and noted the end-tidal carbon dioxide. Next, the subject was switched to a total rebreathing circuit (Read) which had been primed with seven per cent carbon dioxide in oxygen. ${ }^{\$}$. He inhaled three large breaths from this circuit and then relaxed as much as possible while continuing to rebreathe. If the tracing of airway carbon dioxide concentration was steady throughout the respiratory cycle, we permitted rebreathing to proceed until the concentration had increased 1.5-2.0 per cent. Both ventilation and carbon dioxide concentration were monitored throughout.

Ventilation was measured with a pneumotachograph head (Fleisch \#2 or \#3) incorporated in the inspiratory limb of each circuit. Both the flow signal and its integral (i.e. volume) were recorded. Volume was regularly calibrated with an air calibration syringe, and correction factors were applied for the density and viscosity of the two gas mixtures inhaled (air and carbon dioxide in oxygen). Resting tidal volume, frequency and ventilation were calculated from the averaged inspired volumes and respiratory cycle lengths of one minute of recorded ventilation. Values of instantaneous ventilation during the carbon dioxide responses were computed from the averaged tidal volumes and respiratory cycle lengths of three consecutive breaths. All ventilatory volumes were expressed at B.T.P.S.

End-tidal and airway carbon dioxide concentrations were measured with a Perkin-Elmer \# 1100 mass spectrometer, which was calibrated regularly with Canadian Liquid Air specialty gases. Values of dried airway or end-tidal carbon dioxide concentrations were converted to tensions, employing the measured barometric pressure of the day of testing and assuming end-tidal gas to be fully saturated with water vapour at $37^{\circ} \mathrm{C}$. To represent the ventilatory response to carbon dioxide we assumed ventilation related linearly to airway $\mathrm{PCO}_{2}$ during rebreathing and calculated the slope of the least squares linear regression of at least ten pairs of data points taken at regular intervals throughout the test.

To assess results before and at various times after administrations and between each type of administration, we employed an analysis of variance, with values of ventilation and ventilatory respone to added carbon dioxide normalized for body surface area. A p value of 0.05 or less was accepted as significant.

\section{RESULTS}

Except for mild itching after epidural morphine and the usual subjective effects of acute hypercarbia, subjects experienced no side effects during the periods in which measurements were made. However, commencing six or seven hours after epidural injection, three subjects developed nausea and/or dysphoria, and noted difficulty in micturition. These side effects, which are described more fully in the accompanying report? were particularly troublesome in the first two subjects who received epidural morphine $7.0 \mathrm{mg}$. Therefore, we did not proceed further with studies at this dose. Statistical analysis was possible only on the results of morphine $3.5 \mathrm{mg}$.

Results are displayed in Tables I and II and in Figures I, 2 and 3. Control values of ventilation, $\mathrm{PET}_{\mathrm{CO}_{2}}$ and the slope of the ventilatory response to carbon dioxide were typical of healthy young male subjects (Tables I and II).

Subcutaneous morphine $3.5 \mathrm{mg}$ produced small and insignificant reductions of ventilation, tidal volume and frequency, increased $\mathrm{PET}_{\mathrm{CO}_{2}}$ slightly and did not significantly alter the slope of the ventilatory response to added carbon dioxide (Table I, Figure 1). Subcutaneous morphine $7.0 \mathrm{mg}$ had similar effects (Table II, Figure 1).

Epidural morphine $3.5 \mathrm{mg}$ reduced ventilation and tidal volume and increased $\mathrm{PET}_{\mathrm{CO}_{2}}$, all changes being significant 90 to 150 minutes after injection (Table 1. Figure 1). The increment of $\mathrm{PET}_{\mathrm{CO}_{2}}$ tended to progress with time. The slope of the ventilatory response to added carbon dioxide was not detectibly different from control until 360 minutes after injection, at which time it decreased considerably (Table I, Figure 2). Epidural morphine $7.0 \mathrm{mg}$ produced similar changes (Table II, Figure 1).

Comparing epidural to subcutaneous injections of morphine $3.5 \mathrm{mg}$, ventilation, tidal volume and carbon dioxide response slope were all significantly less with epidural administrations at various times between 150 and 360 minutes after injection (Table I, Figure 1). The difference in carbon dioxide response which was observed at 360 minutes was due to a reduced tidal volume response to carbon dioxide $(0.52 \pm 0.191 / \mathrm{kPa}$ after epidural morphine, compared to $0.91 \pm 0.13$ 1/kPa after subcutaneous morphine, $p<0.02$ ) with frequency response relatively unchanged. There were similar differences between epidural and subcutaneous injections of morphine $7.0 \mathrm{mg}$ (Table II, Figure 1).

Two subjects were re-tested twenty-four hours 
TABLE I

Ventilatory EfFEcts: MoRphine $3.5 \mathrm{mg}$ $\mathrm{n}=4$

\begin{tabular}{|c|c|c|c|c|c|c|}
\hline & \multicolumn{3}{|c|}{ Subcutaneous } & \multicolumn{3}{|c|}{ Epidural } \\
\hline & $\begin{array}{c}\dot{V}_{1} \\
(1 / \min )\end{array}$ & $\begin{array}{l}\mathrm{PET}_{\mathrm{CO}_{2}} \\
(\mathrm{kPa})\end{array}$ & $\begin{array}{l}\mathrm{CO}_{2} \text { Response } \\
\left(1 / \mathrm{min} \cdot \mathrm{kPa}^{-1}\right)\end{array}$ & $\begin{array}{c}\dot{V}_{\mathrm{I}} \\
(\mathrm{l} / \mathrm{min})\end{array}$ & $\begin{array}{l}\operatorname{PET}_{\mathrm{CO}_{2}} \\
(\mathrm{kPa})\end{array}$ & $\begin{array}{l}\mathrm{CO}_{2} \text { Response } \\
\left(1 / \mathrm{min} \cdot \mathrm{kPa}^{-1}\right)\end{array}$ \\
\hline Control & $6.04 \pm 0.36$ & $5.5 \pm 0.09$ & $13.80 \pm 2.55$ & $6.33 \pm 0.61$ & $5.6 \pm 0.15$ & $17.78 \pm 4.73$ \\
\hline $30 \mathrm{~min}$. & $5.43 \pm 0.59$ & $5.5 \pm 0.11$ & $14.25 \pm 5.63$ & $5.09 \pm 0.42$ & $5.7 \pm 0.14$ & $17.70 \pm 5.10$ \\
\hline $90 \mathrm{~min}$. & $5.78 \pm 0.40$ & $5.6 \pm 0.08 *$ & $15.75 \pm 2.63$ & $4.71 \pm 0.40^{*}$ & $5.9 \pm 0.14^{*}$ & $11.70 \pm 3.68$ \\
\hline $150 \mathrm{~min}$. & $5.25 \pm 0.58$ & $5.6 \pm 0.14$ & $12.60 \pm 3.30$ & $4.57 \pm 0.42 * \dagger$ & $5.9 \pm 0.11$ & $13.35 \pm 2.70$ \\
\hline $240 \mathrm{~min}$ & $5.90 \pm 0.5 \mathrm{l}$ & $5.7 \pm 0.13^{*}$ & $11.48 \pm 4.65$ & $4.83 \pm 0.61^{*}$ & $6.0 \pm 0.13^{*}$ & $13.50 \pm 5.25$ \\
\hline $360 \mathrm{~min}$. & $6.50 \pm 0.68$ & $5.7 \pm 0.11^{*}$ & $17.85 \pm 5.18$ & $4.80 \pm 0.59^{*}$ & $6.1 \pm 0.16^{*}$ & $9.23 \pm 4.20^{*} \dagger$ \\
\hline
\end{tabular}

All values are means \pm S.E.M.

Within the analysis of variance:

* Significantly different from control values, $p<0.05$.

$\uparrow$ Significantly different from corresponding subcutaneous values, $p<0.05$.
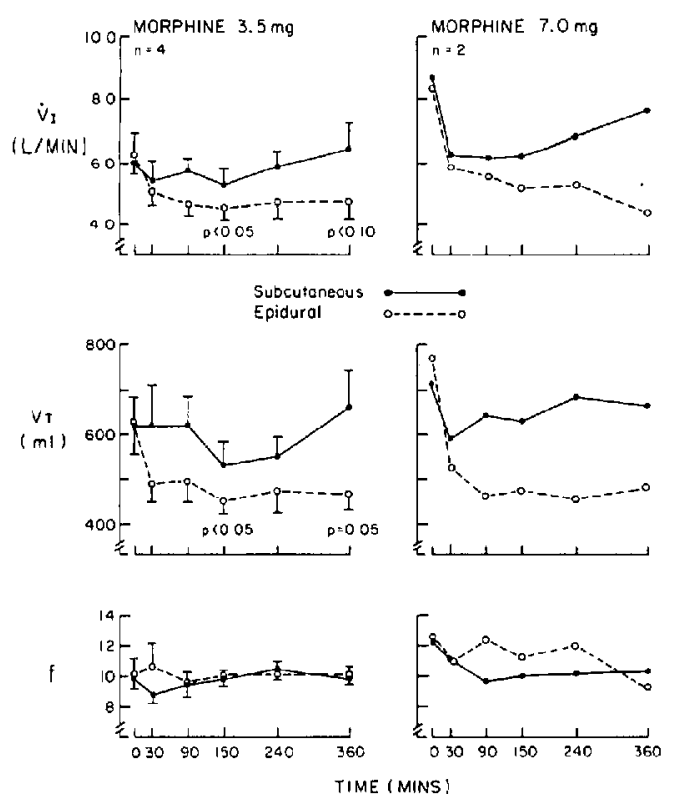

FIgURE 1 Ventilation and its components, tidal volume and breathing frequency, before and at intervals after morphine $3.5 \mathrm{mg}$ (left) $7.0 \mathrm{mg}$ (right), given by subcutaneous and lumbar epidural routes (closed and open circles respectively). Data depicted for the $3.5 \mathrm{mg}$ dose represent means \pm S.E.M.; data for the $7.0 \mathrm{mg}$ dose means only. " $p$ " values refer to differences between observations at the same times after subcutaneous and epidural injections.

after both subcutaneous and epidural morphine $3.5 \mathrm{mg}$ (Figure 2). After subcutaneous injections, values of ventilation, $\mathrm{PET}_{\mathrm{CO}_{2}}$ and carbon dioxide response were all close to control. However, after epidural morphine $3.5 \mathrm{mg}$, values of $\mathrm{PET}_{\mathrm{CO}_{2}}$ were elevated $0.4 \mathrm{kPa}$ in each subject (mean twenty-four hour $\mathrm{PET}_{\mathrm{CO}_{2}} 5.9 \mathrm{kPa}$, mean control $5.5 \mathrm{kPa}$ ), and the slopes of the carbon dioxide response remained slightly depressed (mean
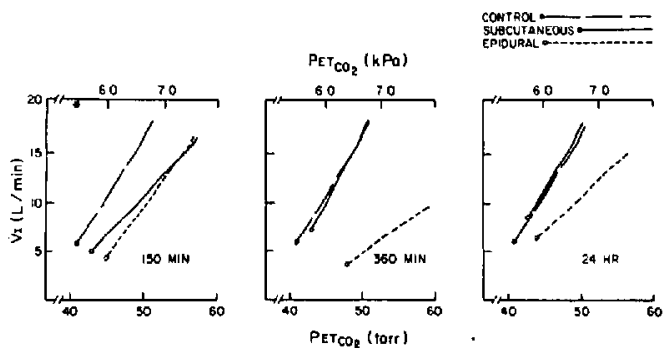

Figure 2 Ventilation, $\mathrm{PET}_{\mathrm{CO}_{2}}$ and the ventilatory responses to added carbon dioxide of one subject 150 minutes, 360 minutes and twenty-four hours after subcutaneous and lumbar epidural morphine $3.5 \mathrm{mg}$. Points represent resting values of ventilation and $\mathrm{PET}_{\mathrm{CO}_{2}}$ : lines extending from points are the calculated carbon dioxide response slopes. Epidural morphine caused marked ventilatory depression 360 minutes after injection - when the effect of subcutancous morphine had dissipated. Depression after epidural morphine persisted for twenty-four hours.

twenty-four hour slope $13.3 \mathrm{l} / \mathrm{min} \cdot \mathrm{kPa}^{-1}$, mean control $18.31 / \mathrm{min} \cdot \mathrm{kPa}^{-1}$ ). By forty-eight hours after epidural injections, these variables were close to control.

To analyze further the time course of carbon dioxide response in the first six hours after epidural morphine, we expressed the changes in individual carbon dioxide response slopes at each interval following injection as a percentage of the maximum change in response slope, where

\section{Maximum per cent effect $=$}

$$
\frac{\text { observed response }- \text { control response }}{\text { maximum response }- \text { control response }} \times 100
$$

The results of 3.5 and $7.0 \mathrm{mg}$ studies when combined, revealed that carbon dioxide response slopes were significantly less than control 90, 240 
TABLE II

VENTILATORY EFFECTS: MORPHINE $7.0 \mathrm{mg}$ $n=2$

\begin{tabular}{|c|c|c|c|c|c|c|}
\hline & \multicolumn{3}{|c|}{ Subcutaneous } & \multicolumn{3}{|c|}{ Epidural } \\
\hline & $\begin{array}{c}\dot{V}_{1} \\
(1 / \mathrm{min})\end{array}$ & $\begin{array}{l}\mathrm{PET}_{\mathrm{CO}_{2}} \\
(\mathrm{kPa})\end{array}$ & $\begin{array}{l}\mathrm{CO}_{2} \text { Response } \\
\left(1 / \mathrm{min} \cdot \mathrm{kPa}^{-1}\right)\end{array}$ & $\begin{array}{c}\dot{V}_{1} \\
(1 / \mathrm{min})\end{array}$ & $\begin{array}{l}\mathrm{PET}_{\mathrm{CO}_{2}} \\
(\mathrm{KPa})\end{array}$ & $\begin{array}{l}\mathrm{CO}_{2} \text { Response } \\
\left(1 / \mathrm{min} \cdot \mathrm{kPa}^{-1}\right)\end{array}$ \\
\hline Control & 8.78 & 5.5 & 25.58 & 8.35 & 5.5 & 15.90 \\
\hline $30 \mathrm{~min}$. & 6.30 & 5.5 & 16.88 & 5.59 & 5.6 & 15.90 \\
\hline $90 \mathrm{~min}$. & 6.20 & 5.5 & 18.45 & 5.58 & 5.6 & 17.25 \\
\hline $150 \mathrm{~min}$. & 6.25 & 5.6 & 15.75 & 5.20 & 6.0 & 21.60 \\
\hline $240 \mathrm{~min}$. & 6.88 & 5.5 & 20.18 & 5.32 & 6.1 & 12.68 \\
\hline $360 \mathrm{~min}$. & 7.65 & 5.4 & 19.95 & 4.47 & 6.1 & 3.97 \\
\hline
\end{tabular}

All values are means.

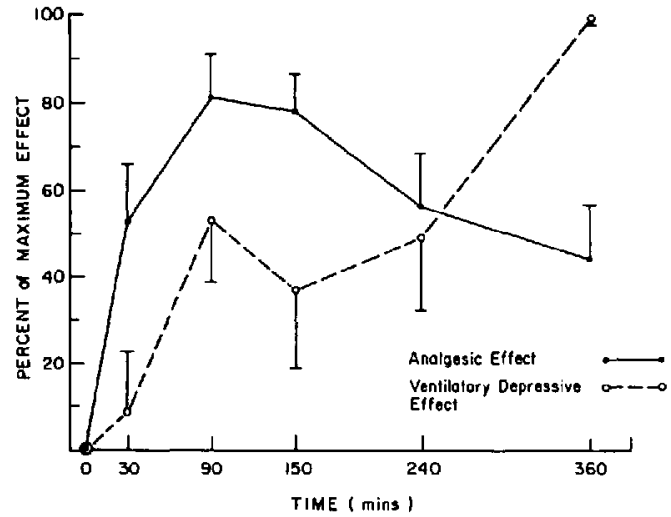

Figure 3 Time courses of analgesic and ventilatory depressive effects of lumbar epidural morphine. Analgesia was estimated with the sub-maximum effort tourniquet technique applied to the leg, ventilatory depression with the slope of the response to added carbon dioxide. Both sets of data were collected from the same subjects studied at the same times (tourniquet test data from reference \#7). Depicted are means \pm S.E.M. of per cent of maximum effect. Ventilatory depression increased as analgesia of the lower limbs waned.

and 360 minutes after administration $(p<0.05)$ and that these reductions appeared to progress with time (Figure 3).

\section{Discussion}

In this study of healthy volunteers, small doses of morphine injected into the epidural space produced more ventilatory depression than the same doses of morphine administered subcutaneously. The added effects of epidural morphine were unusual in that they were delayed in onset, very prolonged, and primarily due to reductions of tidal volume.

Subcutaneous morphine 3.5 and $7.0 \mathrm{mg}$ had minimal ventilatory effects, in agreement with previous reports. ${ }^{9,10}$. Elevations of end-tidal $\mathrm{PCO}_{2}$ were only slight and there was no detectable change in the slope of the ventilatory response to carbon dioxide (Tables I and II). The same small doses of morphine given to the same subjects, but by lumbar epidural injection, had definite effects. Ventilation was clearly reduced and $\mathrm{PET}_{\mathrm{CO}_{2}}$ elevated beginning 90 minutes after injection, with $\mathrm{PET}_{\mathrm{CO}_{2}}$ values tending to increase further with time (Tables I and II, Figures 1 and 2). Changes in ventilation were proportionately greater than changes in $\mathrm{PET}_{\mathrm{CO}_{2}}$ and therefore the latter may have underestimated the true magnitude of alveolar hypoventilation $\left(\mathrm{Pa}_{\mathrm{CO}_{2}}\right.$ values not determined). The slope of the ventilatory response to added carbon dioxide, when expressed as a percentage of maximum effect, was also reduced from control beginning 90 minutes after injection (Figure 3). The greatest change in carbon dioxide response occurred between 240 and 360 minutes. when slopes for all subjects decreased markedly (Tables I and 1I, Figure 3).

These effects of epidural morphine not only exceeded those associated with the same doses of morphine given subcutaneously (Table I, Figures $($ and 2), but appeared to be proportion. ately greater than effects reported for morphine $10-15 \mathrm{mg}$ given intramuscularly or intravenously. ${ }^{9-1.3}$ In addition to being greater, the ventilatory effects of epidural morphine were qualitatively different, in that the added depressions of ventilation and of the respone to carbon dioxide (compared to subcutaneous injections) were due solely to reductions of tidal volume (Figure 1) and of the tidal volume response to carbon dioxide. This is in contrast to the usual ventilatory changes associated with morphine given parenterally, which are a reduction of breathing frequency alone, or a reduction of both frequency and tidal volume together. ${ }^{11,12.14}$

Another unusual feature of epidural morphine was the time course of its ventilatory effects. Changes appeared to evolve slowly with time, 
until six hours after administration (Table I, Figures 1,2 and 3). We did not follow ventilatory variables after six hours (it would have been impossible to do so properly because of the unpleasant side effects subjects were experiencing at that time) and it is possible that the changes observed at six hours did not represent maximum magnitude or duration of effect. Indeed data from two of our subjects, who were re-tested on the day after injection, indicate that ventilatory depression may have persisted to a minor degree for as long as twenty-four hours (Figure 2).

Our finding of ventilatory depression appears inconsistent with the results of two previous studies of epidural narcotic in volunteers, in whom a definite ventilatory effect was not observed. ${ }^{5,6}$ We believe that important ventilatory changes may have been missed in these studies, because resting values of ventilation and $\mathrm{PCO}_{2}$ were not determined, and carbon dioxide responses were considered only within three hours of an epidural injection. Our observations of delayed and marked depression are in keeping with clinical reports of ventilatory failure occurring in patients four or more hours after epidural morphine, ${ }^{3.4}$ and support the view that this complication is a toxic rather than an idiosyncratic response, as it developed consistently in all subjects whom we tested.

What is the explanation for this unexpected marked, delayed and very prolonged depression of ventilation after epidural morphine in man? We cannot account for it on the basis of vascular absorption. The same doses of morphine administered subcutaneously which resulted in similar serum morphine levels ${ }^{7}$ failed to cause the same depression; indeed, ventilatory depression after epidural morphine was maximum in this study long after morphine had become undetectible in the serum. ${ }^{?}$

It is known that after epidural administration in man, morphine appears in the lumbar CSF, ${ }^{15}$ from where, on the basis of anirnal data, it is probably cleared only very slowly. ${ }^{16}$ Foreign materials such as radio-pharmaceuticals employed for cisternography, which remain in the lumbar sub-arachnoid space for hours, gradually move rostrally in the circulating CSF to fill the cisterns at the base of the skull 3-6 hours after injection, where they may persist for an additional twenty-four hours or more. ${ }^{17,18} \mathrm{We}$ believe that a similar slow cephaled circulation of morphine in the CSF with gradually increasing uptake and persistence in more rostrally placed neural structures is the explanation for the de- layed and prolonged ventilatory depression we observed. This mechanism would also account for other delayed effects of epidural morphine observed in man, such as pin-point pupils in patients $\mathrm{s}^{3.4}$ and nausea, vomiting and dysphoria in volunteers. $^{7}$

The rostral site in the neural axis where epidurally administered morphine acts to produce ventilatory depression could be spinal and/ or supra-spinal, i.e. within the spinal cord and/or in the brain. It is known that large doses of narcotic given parenterally can increase the tonic activity of chest wall muscles through a direct or indirect action on spinal cord motorneurons and, as a result, produce dyspnoea and hypoventilation. ${ }^{19,20}$ Such an effect on the spinal cord could presumably also develop as a result of local uptake of narcotic from the CSF. Also, tiny doses of morphine $(10-50 \mu \mathrm{g})$ injected into the subarachnoid space around the brainstem of the cat produce marked ventilatory depression, ${ }^{21}$ probably by uptake into and actions on ventilatory control neurons in the medulla and pons. We favour this supra-spinal action to explain our findings because our subjects did not experience the dyspnoea and the increased tone of chest wall muscles normally associated with the spinal effect. However, an action at either spinal or supra-spinal site would be consistent with both a marked and a different ventilatory depressant effect compared to parenteral administration, due to the probability of higher spinal cord and brain concentrations of narcotic than are usually achieved with parenteral injection, and a different distribution of narcotic within neural structures. ${ }^{22}$

If morphine moves rostrally in the CSF after epidural administration one would predict a changing pattern of neural effects with time, increasing effects from actions at more rostral sites in the neuraxis concurrent with dissipating effects from actions at more caudal sites. Consistent with this hypothesis we observed that, as ventilatory depression intensified, analgesia of the lower limb waned (Figure 3); somewhat inconsistent, however, was our failure to detect delayed analgesia of the upper limb. ${ }^{7}$ According to the description of CSF circulation proposed by Di Chiro, ${ }^{17}$ morphine would migrate cephalad in the subarachnoid space anterior to the dentate ligament and the cord and thence into the pontile cistern anterior to the brain stem, without gaining immediate access to the dorsal horns of the upper cord, the site of action for analgesia. ${ }^{23}$ This could account for our failure to detect delayed anal- 
gesia of the upper limb. In addition, circulation of morphine in the anterior spaces would explain the marked effect we observed on the ventilatory respone to added carbon dioxide in comparison to effects on ventilation and $\mathrm{PET}_{\mathrm{CO}_{2}}$, since the central carbon dioxide $/ \mathrm{H}^{+}$chemoreceptors are located superficially in the anterior medulla bathed by CSF in the anterior cisterns, ${ }^{24}$ while "respiratory centre" neurons are more deeply situated.

Our results suggest that after small epidural doses of morphine, ventilatory depression develops as analgesia is dissipating (Figure 3). In the clinical setting, this could act to the patient's benefit in that returning pain would antagonize ventilatory depression. However, we suspect that this advantage would be lost with either repeated or very large epidural doses of narcotic which would reduce or eliminate returning pain. It is interesting to note that of the two reported cases of severe ventilatory failure after small epidural doses of morphine, ${ }^{3,4}$ one occurred after a second administration.

How might the risk of ventilatory depression after epidural morphine be reduced to a minimum? Reducing the dose of morphine could help, but $3.5 \mathrm{mg}$ would appear to be close to the minimal dose required by the epidural route for pain relief. If our hypothesis regarding mechanism is correct. narcotic agents which are more rapidly cleared from CSF and neural structures might have lesser ventilatory effects. This remains to be investigated.

In the meantime it would seem prudent to restrict the administration of narcotics by either the intrathecal or the epidural route to patients who can be monitored closely for the subsequent 12-24 hours.

\section{ACKNOWLEDGEMENTS}

The authors gratefully acknowledge the contributions to this study made by Drs. B. Mezon, A. Lam, G.P. Varkey, M. Hirst and Mrs. L. Nolan.

\section{REFERENCES}

1. Glynn, C.J., Mather, L.E., Cousins, M.J., Wilson, P.R. \& Graham, J.R. Spinal narcotics and respiratory depression. Lancet 2: $356-357$ (1979).

2. Davies, G.K., Tolhurst-Cleaver, C.L. \& JAMES, T.L. CNS despression from intrathecal morphine. Anesthesiology 52 (3): 280 (1980).

3. Christensen, V. Respiratory depression after extradural morphine. Br. J. Anaesth. 52: 841 (1980).
4. Reiz, S. \& Westberg, M. Side effects of epidural morphine. Lancet 2: 203-204 (1980).

5. Torda, T.A., Pybus, D.A., Liberman, H.. Clark, M. \& Crawford, M. Experimental comparison of extradural and I.M. morphine. $\mathrm{Br}$. J. Anaesth. 52: 939-942 (1980).

6. Bromage, P.R., Camporest, E. \& Leslie, J, Epidural narcotics in volunteers: Sensitivity to pain and to carbon dioxide. Pain 9: 145-160(1980).

7. Thompson, W.R., Smith, P.T., Hirst, M., VARKEY, G.P. \& KNILL, R.L. Regional analgesic effect of epidural morphine in volunteers. Can. Anaesth. Soc. J. 28 : 530-536 (1981).

8. READ, D.J.C. A clinical method for assessing the ventilatory response to $\mathrm{CO}_{2}$. Australas. Ann. Med. 16: 20-26 (1967).

9. Loeschcke, H.H., Sweel, A., Kough, R.H. \& LAMBERTSEN, C.J. The effect of morphine and of meperidine upon the respiratory response of normal men to low concentrations of inspired carbon dioxide. J. Pharmacol. Exp. Ther. 108: 376-383 (1953).

10. WeIl, J.V., MCCUllough, R.F., Kline, J.S. \& SoDAL, I.E. Diminished ventilatory response to hypoxia and hypercapnia after morphine in normal man. N. Eng. J. Med. 292: 1103-1106 (1975).

11. Eckenhoff, J.E. \& Oech, S.R. The effects of narcotics and antagonists upon respiration and circulation in man. Clin. Pharmacol. Ther. 1: 483-524 (1960).

12. Dripps, R.D. \& ComroE, J.H. Clinical studies on morphine. I. The immediate effect of morphine administered intravenously and intramuscularly upon the respiration of normal man. Anesthesiology 6: 462-468 (1945).

13. Wendel, H. \& Lambertsen, C.J. Morphine and meperidine as respiratory depressants in man. Fed. Proc. 16: 345 (1957).

14. Orkin, L.R., EgGe, R.K. \& Rovenstine, E.A. Effect of nisentil, meperidine and morphine on respiration in man. Anesthesiology 16: 699-707 (1955).

15. Magora, F., Olshwang, D., Eimerl, D., Shorr, J., Katzenelson, R., Cortev, S. \& DAvidson, J.T. Observations on extradural morphine analgesia in various pain conditions. $\mathrm{Br} . \mathrm{J}$. Anaesth. 52: 247-252 (1980),

16. Yaksh, T.L. \& Rudy, T.A. Studies on the direct spinal action of narcotics in the production of analgesia in the rat. J. Pharmacol. Exp. Ther. 202: $411-428$ (1977).

17. Di ChIRo, G. Observations on the circulation of the cerebrospinal fluid. Acta Radiol. Scand. 5: 9881002 (1966).

18. JAMES, A.E. Diagnostic nuclear medicine. Section 20, Chapter 30, Baltimore: The Williams and Wilkins Company (1976).

19. Freund, F.G., Martin, W.E., Wong, K.C. \& HoRnbein, T.F. Abdominal-muscle rigidity induced by morphine and nitrous oxide. Anesthesiology 38: 358-362 (1973).

20. Sokoll, M.D., Hoyt, J.L. \& Gergis, S.D. Studies in muscle rigidity, nitrous oxide, and narcotic analgesic agents. Anesth. Analg. 51: 16-20 (1972).

21. Flórez, J., McCarthy, L.E. \& Borison, H.L. A comparative study in the cat of the respiratory effects of morphine injected intravenously and into 
the cerebrospinal fluid. J. Pharmacol. Exp. Ther. 163: 448-455 (1968).

22. Herz, A. \& Teschemacher, H.J. Activities and sites of antinociceptive action of morphine-like analgesics. Advances in Drug Research 6: 79-119 (1971).

23. Yaksh, T.L. \& RudY, T.A. Narcolic analgesics: CNS sites and mechanisms of action as revealed by intra-cerebral injection techniques. Pain 4: 299 359 (1978).

24. Mitchell, R.A., Loeshcke, H.H., Massion, W.H. \& Severinghaus, J.W. Respiratory responses mediated through superficial chemosensitive areas on the medulla. J. Appl. Physiol. 18: $523-533$ (1963).

\section{RÉSUMÉ}

La ventilation, la $\mathrm{PCO}_{2}$ de fin d'expiration et la réponse respiratoire à l'inhalation de $\mathrm{CO}_{2}$ ont été étudiées chez des volontaires avant et à intervalles allant jusqu'à six heures, après l'administration par voie péridurale de morphine aux doses de 3.5 et de $7 \mathrm{mg}$. Les mèmes paramètres ont été étudiés après l'administration par voie sous-cutanée des mêmes doses de cet agent. L'administration de morphine par voie souscutanée a été suivie d'une élévation légère de la $\mathrm{PCO}_{2}$ de fin d'expiration mais n'a pas modifié la réponse à l'addition de $\mathrm{CO}_{2}$. La morphine administrée par voie péridurale amenait une diminution de la ventilation et une augmentation, croissante avec le temps, de la $\mathrm{PCO}_{2}$ de fin d'expiration; six heures après l'administration péridurale, la réponse respiratoire à l'inhalation de $\mathrm{CO}_{2}$ était diminuée de façon considérable. Ces effets respiratoires ont persisté durant 24 heures chez deux des sujets étudiés. Les effets additionnels de la morphine administrée par voie péridurale étaient dus principalement à une diminution du volume courant et de la réponse en volume courant à l'inhalation de $\mathrm{CO}_{2}$. Nous concluons que la morphine par voie péridurale produit une dépression tardive et très prolongée de la ventilation et que cette dépression est plus importante (et différente) que celle qui suit l'adminsitration de la même dose de cet agent par voie sous-cutanée. La dépression respiratoire après administration de morphine par voie péridurale s'installe lentement alors que les effets d'analgésie aux membres inférieurs s'atténuent. 